\title{
INFLATION: IMPERFECT MARKETS AND GOVERNMENT POLICIES
}

Robert R. Nathan

Everybody agrees that inflation is a costly economic disease -an economic menace. It is like a cancer metastasizing through the economy adversely affecting investment, productivity, our international competitive capabilities, resource allocation, in fact undermining almost every aspect of the American economy.

So far, we have made little progress in overcoming more than a decade of serious inflation. It will not come easily and quickly, but we do not have to trade off other high and important priority goals in the fight against inflation. In the war against inflation, we basicaliy have four alternatives:

One alternative is a deep and enduring recession. To achieve a measurable drop in the consumer price index or in the GNP deflator via this alternative, it will be necessary to resign ourselves to a substantial increase in unemployment over a significant period of years. The chance of significantly reducing the rate of inflation by a mild recession of moderate duration is remote. As a matter of fact, a short and shallow recession might aggravate inflation rather than contribute to its reduction because of lower investment and poor productivity. The

Mr. Nathan is Chairman of Robert R. Nathan Associates, Inc., Washington, D.C. 
cost of a deep recession for several years would run into the hundreds of billions of dollars. This does not mean that we can ignore or risk overheating the economy.

A second alternative, which I also find disturbing, is a decision to live with inflation. It is an alternative that encompasses a relaxation of concern over inflation along with attempts to index everything. That notion was the fad not too long ago. There are many businessmen who only a few years ago said that if four or five per cent inflation persisted over a long period of time, the economy would fall apart, that we could not live with it. Now they say, "Wel1, seven or eight per cent inflation isn't so bad!" It will get worse if we do not seek to make it better. Seeking ways to live with inflation is an unfortunate self-defeating alternative for this country.

The third alternative goes to the other extreme, namely, mandatory controls. As Chairman of the Planning Committee of the War Production Board, I worked closely with the Office of Price Administration, and was impressed with the effectiveness of a mixture of firmness and flexibility. Controls worked quite we 11, but peacetime is not wartime and mandatory controls would be much more difficult to apply now, especially over an extended period of time. The Phase I freeze in 1971 and Phase II worked fairly well, even though most of those administering Nixon's controls did not really believe in what they were doing. Phases III and IV were Iargely phony in principle and practice. In any case, controls are generally undesirable and over any given period of time raise very grave problems. They should not be regarded as a priority alternative, though they may be preferable to runaway inflation. 
The fourth alternative, which I strongly support, is to attack inflation on a number of fronts. The continuing inflation derives from many forces. My vote goes with the Carter program -- with some exceptions. I strongly support Alfred Kahn because he offers possibilities of achieving reasonably positive results. Kahn is highly intelligent, highly motivated and highly realistic. Given support and reasonable time, his efforts can be fruitful.

What disturbed me most about the responses to the Carter antiinflation program of October 24 was the tendency of the media and financiers and some academics to celebrate a Mass for the program even before the ink was dry on the press release. It is unfortunate that this program was written off by cynics before there was any possibility of observing or measuring improvement. Those who say in one breath that we must be patient because it is going to take monetary policy or fiscal restraints a year or two or three to slow the pace of inflation are the same ones who are unwilling to wait even a few months to observe the success or failure of the Carter program. The monetarists who say they are for moderation in applying monetary restraints are anything but moderate with respect to supporting or even tolerating other anti-inflation policies and measures.

of all the Carter programs announced on October 24 and November 1 , there are only two parts to which I take exception. One is a commission and the other is an omission. The former has to do with the degree of rise in interest rates. I have grave doubts whether the one per cent increase in the rediscount rate is going to permit us to avoid a recession next year. The recession prospects for 1979 probably moved 
up from about 25 or 30 per cent prior to this interest rate move to, perhaps, 50 to 60 per cent thereafter. Having said that, I would happily accept a limited recession in exchange for several percentage points decline in the inflation rate. But there are serious doubts that a mild recession is going to have a sizeable effect on the rate of inflation.

The serious omission in Carter's program was the absence of any policies or programs on energy. If we could reduce our oil imports from $\$ 45$ billion dollars or even keep them from rising over the next few years, whether we did it by setting oil import quotas or by becoming serious about relying more on coa 1 , or expanding nuclear energy and intensifying R\&D in other areas, this would strengthen the dollar more than anything else. Actually, it will be remarkable if we can avoid big increases in the value of oil imports. I am concerned about the time when we run out of gold to be sold and when we run out of foreign exchange swaps. As long as the dollar is deteriorating, due in considerable degree to huge oil imports, and the trade deficits are not offset by rapidly enlarging industrial exports, the dollar will lose value and this will exacerbate the difficulties of containing inflation. Makeshift adjustments will work only if other more basic corrective programs are undertaken, especially with respect to energy.

Let me comment further on the monetary picture. As we move against inflation, some degree of monetary restraint is essential and desirable. Where I part company with the monetarists, however, is in my conviction that the complexity and the long persistence of inflation require attacks on a wide range of fronts. Cynicism of many 
monetarists concerning other programs, whether it be regulation, investment, productivity, trade policy, or tax alternatives, is indeed distressing. If you have a complex issue, it seldom lends itself to a simplistic approach. Support for the Carter anti-inflation program does not mean that monetary restraint should be ignored. But, monetary policy should not be an al1-or-nothing proposition as is so often urged by monetarists.

On the subject of monetary restraint, there are grave doubts, looking back at the real growth in the United States over the last year and a half, whether excess demand has actually prevailed and our real growth has been excessive and a major factor in the worsening inflation rate in late 1977 and throughout 1978. There is 7 ittle evidence of recent demand-puil inflation. There are only isolated indications of supply bottlenecks. Reasonable fiscal and monetary policies are needed to prevent excess demand when that threatens to arise; but exclusive reliance on smothering the economy by the blanket approach makes little sense when the economy is not overheated.

If we have a recession next year, the most serious consequence will not be just unemployment. With al1 of our unemployment compensation and welfare arrangements and other transfer payments, the impact on the unemployed will be fairly manageable. What is most disturbing is the effect this will have on levels of investment. We need higher levels of investment, we need to improve productivity, we need more modernization, we need more innovation and we need to keep costs low. Yet a recession due to rising interest rates and monetary restraints will almost certainly bring a decline in the ratio of new industrial 
and commercial investment to GNP. That would lead to a tragic cost in terms of our international competitive position and our productivity. One consequence of a recession next year will be an increase in the federal deficit. A recession will cause a drop in revenues relative to what they otherwise would be. As a matter of fact, a large part of the budget deficits we have had in recent years reflects a shortfall in revenues. With a recession, there is not much doubt that the deficit will go up, no matter how tough, mean, and nasty Carter might be in dealing with the appropriation requests of his agencies.

Let me reiterate my previous suggestion that the Carter antiinflation program ought to be given a fair chance. Most of the criticism to date has been focused on the guidelines, as though they are the whole of the program. I carefully read the President's Message and found many proposals in addition to guidelines. He talked seriously about budget restraints. If he does exercise budget restraints and eliminates some degree of waste and reduces public expenditures without sacrificing essential needs, these will surely provide positive weapons, in the war against inflation.

The President spoke very strongly about regulations. He indicated the need not just to eliminate regulations with respect to airlines and trucking, but to pursue environmental and health objectives through economically sound and flexible means, rather than arbitrary standards. He spoke about the need to weigh the costs against the benefits in environmental and health programs. This emphasis on improved regulation should not be tossed aside flippantly as just rhetoric. Those who 
attribute some of the inflation to regulation are the very ones who are most skeptical about regulatory curtailment and reform serving as weapons against inflation.

The President also talked about agriculture. We have to be tough about price supports. I would much rather see income supports for family farmers than price supports. Looking back on what has happened to agricultural prices in 1978 , it is shocking to remember the tractors rolling on washington one year ago in the demand for higher farm prices. In 1978, farm prices have been a major inflationary factor.

The President talked about trade policies. He did not elaborate in detail, but up to now the President's policies on protectionism have been, on the whole, constructive. I part company with my business and labor friends on protectionist tendencies which are very strong. The President's program of importing more beef makes a great deal of sense. Too many industries immediately raise prices on their products when competitive import prices rise due to the devaluation of the dollar. Reasonably liberal trade policies are needed to prevent administered prices from going through the roof.

The President said he was against any more income tax reductions. I thought what he was trying to say in a subtle manner was "from here on, let's take a hard look at tax reductions and see that different inflationary impacts of different tax cuts are taken into account." Not every tax reduction has the same effect on inflation. The tax cuts of 1978 did not make too much sense in many respects. The cut in the capital gains tax is much less likely to stimulate new investment than would accelerated depreciation or an extension of the investment tax credit to 
structures as well as machinery and equipment. Carter did not develop his tax thoughts fully but the implication was very strong that tax changes designed to increase investment incentives and for having the most impact in lessening the rise in prices should receive priority consideration.

The President went on to discuss competition and productivity. He is committed to developing policies and programs that will improve efficiency and productivity as another step to curtail the rate of inflation.

The price and wage guidelines were stressed by the President, but they certainly are not the whole of his program by any means. Carter is also very much concerned about regulation, trade policy, taxation, investment, agriculture, productivity and other factors influencing inflation.

I have worked closely with labor over the years. I know many of our labor leaders and $I$ do not think all the views of labor are correctly reflected in George Meany's statements. Meany is a strong person. He exercises great influence in the American Tabor movement, but he does not reflect the views of all his union heads or members. There are a considerable number of labor leaders in the United States who are not antagonistic nor unreceptive to efforts to lower the rates of wage increases as long as success can be achieved in lowering the rates of price increases. Many business leaders have publicly committed their companies to support the guidelines.

Even more controversial than the President's program to combat inflation is the issue of the degree of price competition and the 
effectiveness of the market place in our economy. I believe that the market performs a great many very valuable functions, provided it is working reasonably wel1. If it is not functioning well, then it is essential to concentrate on activities that will help improve its operation rather than go the route of more regulations-and more controls and developing other substitutes or alternatives to the market place. Yet, adoption of many of these alternatives can be traced to conclusions, often but not always warranted, that the market is failing to perform as expected. Economists are frequently to blame because they refuse to study the market critically and just assume it works effectively. They ignore the adverse consequences of monopoly or oligopoly or collusion, which not only undermine market forces as much or more than government intervention but actually lead to such intervention. Many in the business community preach free enterprise and practice monopoly. That is a pretty harsh statement but, unfortunately, it applies in many cases. Many businessmen want competition where they buy goods and services but they seek to exercise market power where the selling takes place. There is now far too much interest in this country in mergers and much too little interest in new investment. Many business people want government regulation when they think regulations are going to protect them, but they are against regulations that might help others. I encounter such attitudes all the time because a large portion of my work and that of my associates is in the regulatory field. Many business executives like to increase prices but very seldom do they engage in price cutting. 
In many instances we see larger price increases when demand is less vigorous than when demand is strong. There are cost factors as well as the demand factors, but price competition seems to have weakened. There is a little anecdote that I find amusing. About twenty years ago, when Estes Kefauver was Chairman of the Senate Subcommittee on Monopoly, he had some steel executives testifying before him. He said to one steel executive, "When U.S. Steel raised its price 5.738 per cent, why did you raise your price 5.738 per cent?" The fellow answered, "To be competitive." Laughter practically broke up the session.

We do have very strong tendencies in the direction of administered pricing and rigid costs. Part of our inflation has elements of pricing practices that need to be better understood and corrected. We need to take a hard look at the competitive situation in the market place -- the obstacles and stickiness and rigidities on the downside of prices and costs.

We need another TNEC. In the mid-1930s, Senator Joseph 0'Mahoney of Wyoming introduced a resolution in the Senate calling for a Temporary National Economic Committee. It was established and 0'Mahoney become Chairman. This Committee worked for about three years and was one of the least politically-motivated comnittees ever established in Washington. The TNEC undertook a variety of studies of competition and prices in commodities and product markets and costs. It was one of the best jobs ever done on studying the market place. The work was done at a time when there were no computers and when the data base was nowhere near as large as it is now. 
We need to understand more fuTly and more clearly what is happening in our business practices and structures. It is not easy to explain what is happening or has happened in 1978. Even in the competitive agricultural sector, there is real confusion as to how demand/supply situations are manifesting themselves in the pricing area. With the tremendous crops we have had, why have such inflationary price phenomena arisen? We have not had the shocks that we had in 1973-74 with OPEC, although we will get a shock from higher oil prices pretty soon. We have not had the bad agricultural crop failures abroad that we had in 1973-74. We have not had the two sudden devaluations, although we have had steady devaluation. We are suffering an intensification of inflation, which cannot be attributed to the same kind of external shocks we had in 1973-74 and which are confusing. We need to know more if we are going to prescribe better solutions. We urgently need another TNEC.

The inflation problem is not a partisan issue. Carter would be a strange politician if he were not thinking about what inflation is going to do to him politically. If he does not achieve more success in reducing inflation by 1980 , and if the value of the dollar continues to deteriorate and if productivity does not rise more rapidly and if our level of investment continues to lag, the electorate will demand changes that may not be rational and orderly. Easy promises and political opportunism can be seriously disruptive at a time when the people are properly demanding an end to inflation and all its horrible impacts.

I do not believe that success will be forthcoming by relying only on monetary and fiscal restraints. Some such restraints are needed as 
part of a total program, but we must look to many other areas of policy. Leaders in academic circles and in financial circles should provide constructive leadership. It is going to take some time to show results. Alfred Kahn has my vote and I urge a little patience for his efforts. The true issue concerning inflation is whether we are really serious in seeking to move toward price stability. If we are serious we will support efforts on a broad front and not just seek a trade off between inflation and recession or depression. 